\title{
INFLUENCE OF KINEMATIC FACTORS OF FRICTION STIR WELDING ON THE CHARACTERISTICS OF WELDED JOINTS OF FORGED PLATES MADE OF EN AW 7049 A ALUMINIUM ALLOY
}

\author{
Milenko Perović, Sebastian Baloš, Dražan Kozak, Darko Bajić, Tomaž Vuherer
}

Original scientific paper In this paper, the influence of rotation speed and welding speed on the impact strength, microstructure and cross section micro hardness of FSW welded joints of Al-Zn-Mg-Cu high strength aluminium alloy is studied. Rotation speed was varied from $750 \mathrm{~min}^{-1}$ to $850 \mathrm{~min}^{-1}$ and welding speed from 60 $\mathrm{mm} / \mathrm{min}$ to $80 \mathrm{~mm} / \mathrm{min}$. It was found that the energy of crack propagation is up to three times higher than the energy of crack initiation. This ratio was found by testing the Charpy notched specimens taken from left and right from the weld centre, $4 \mathrm{~mm}$ from the notch in a direction opposite to a direction of welding. Micro hardness distribution in the nugget does not show large dissipation of value regardless if the measuring point is in the upper or lower section of the nugget. Weld microstructure characteristics and zones are clearly defined at the basis of grain size and material flow.

Keywords: dynamic recrystallization; friction stir welding; impact strength; micro hardness distribution

\section{Utjecaj kinematičkih faktora zavarivanja trenjem miješanjem na karakteristike zavarenog spoja kovanih ploča od legure aluminija EN AW 7049 A}

Izvorni znanstveni članak U radu se analiziraju utjecaji broja okretaja i brzine zavarivanja na udarnu žilavost, metalografska obilježja i raspodjelu mikrotvrdoće po površini poprečnog presjeka FSW zavarenog spoja kovanih ploča od visokočvrste legure aluminija faznog sastava Al-Zn-Mg-Cu. Broj okretaja je mijenjan u rasponu od $750 \mathrm{~min}^{-1}$ do $850 \mathrm{~min}^{-1}$, a brzina zavarivanja od $60 \mathrm{~mm} / \mathrm{min}$ do $80 \mathrm{~mm} / \mathrm{min}$. Razdvajanjem energije inicijacije pukotine od energije potrebne za njezinu propagaciju, uočava se da je čak i do tri puta veća vrijednost energije koja je potrebna za njezinu propagaciju. Odnos energije inicijacije 1 energije propagacije je dobiven ispitivanjem Charpy epruvete sa zarezom u središtu, lijevo i desno od središta metala šava 4 mm u smjeru suprotnom od smjera zavarivanja. Distribucija mikrotvrdoće metala šava ne pokazuje veliko rasipanje vrijednosti bez obzira da li je mjerno mjesto u gornjoj ili donjoj razini površine zavarivanih komada. Na mikrograficima jasno se uočavaju zone strukturnih sadržaja zavarenog spoja na osnovi veličine zrna i linija tečenja materijala.

Ključne riječi: dinamička rekristalizacija; distribucija mikrotvrdoće; udarna žilavost; zavarivanje trenjem miješanjem

\section{Introduction}

Until the discovery of friction stir welding two and a half decades ago, weldability of thermally strengthened (tempered) aluminium alloys was a serious technological problem. Among the alloys that were not weldable were the alloys of the type $2 \mathrm{xxx}$, and especially type $7 \mathrm{xxx}$ having the composition $\mathrm{Al}-\mathrm{Zn}-\mathrm{Mg}-\mathrm{Cu}$, Fig. 1.

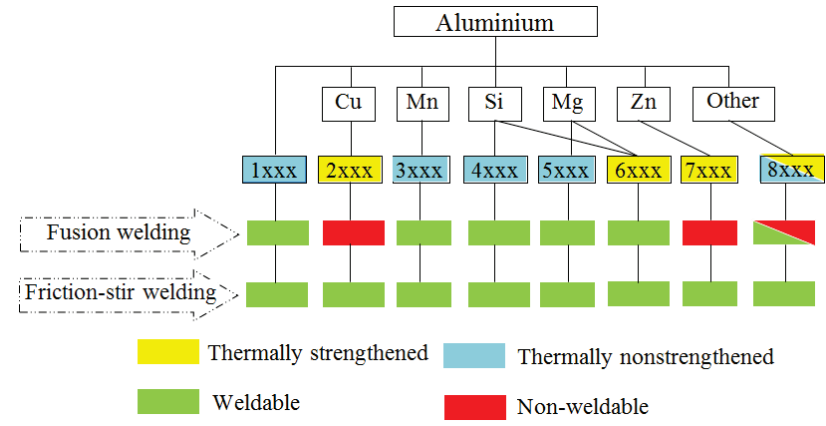

Figure 1 Weldability of various aluminium alloys by fusion and friction stir welding [1]

Aluminium alloys from this class are characterized by high strength, low toughness and increased sensibility to cracking. Therefore, it is of primary interest to acquire welded joints (with heterogeneous structure) of a favourable compromise of features enabling their application in the aviation and military technology. Such demand could be met only by a welding technology with a low heat input, which generated a lower temperature than the melting temperature of the alloy to be welded [1].

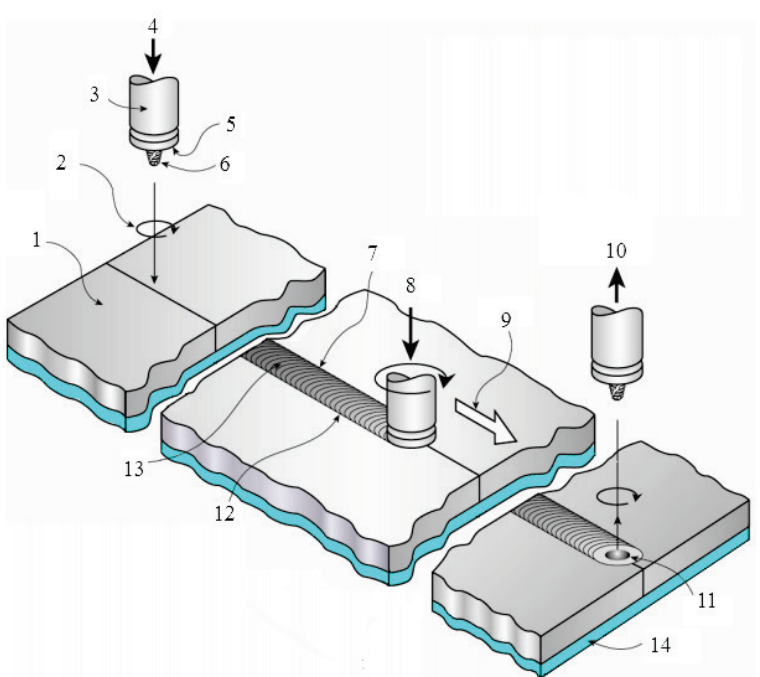

Figure 2 Illustrated scheme of welding by friction mixing [2] (1 - base metal, 2 - direction of tool rotation, 3 - weld tool, 4 - downward movement of tool, 5 - tool shoulder, 6 - pin, 7 - advancing side of weld, 8 - axial force, 9 - direction of welding, 10 - upward movement of tool, 11 - exit hole, 12 - retreating side of weld, 13 - weld face and 14 - base plate)

The welded joint is asymmetrical due to a difference between speed vectors on tool sides. When the vectors of welding speed and tool rotation coincide, it is advancing side (AS) and when the vectors of two most influenced 
kinematic parameters are opposite, it is the retreating side (RS) [2]. Fig. 2 shows the illustrative scheme of friction stir welding with key features and kinematic parameters.

\section{Experimental}

The experiment was aimed to find the influence of input kinematic parameters such as welding speed $(v)$ and tool rotation speed $(n)$ on metallurgical and mechanical characteristics of welded joints. Base material was the high strength aluminium alloy similar to EN AW 7049 in T652 heat treated condition produced by domestic raw material within the industrial conditions $[3,4]$.

Casting was made from several batches and after the receipt of liquid metal, at the temperature of $850{ }^{\circ} \mathrm{C}$ alloyed elements were added in the form of pure metals or pure alloys. Also, the degassing and refining was done to eliminate the presence of hydrogen from metal and dross. Free casting is made in two phases [5]. In the first phase the chuck is compressed on the press of nominal power $50 \mathrm{MN}$ with the temperature of tool of $150 \div 200{ }^{\circ} \mathrm{C}$, temperature of insole of $420 \div 440{ }^{\circ} \mathrm{C}$ and casting velocity of $3 \mathrm{~mm} / \mathrm{s}$ at the height of $25 \pm 1 \mathrm{~mm}$. In the second phase, at the same press and at the same heat regime, but with the casting velocity of $2 \mathrm{~mm} / \mathrm{s}$, intermediate product is cast at the height of $15 \pm 1 \mathrm{~mm}$. As regards the processing of dissolved calcining, the piece is heated to $470{ }^{\circ} \mathrm{C}$ and stayed at that temperature for 60 minutes, and then was quickly cooled in water at maximum $15 \mathrm{~s}$ [6]. To remove the residual voltage from casting, pieces are cold deformed from $1 \%$ to $3 \%$. Fig. 3 shows the finished cast plate of $760 \times 660 \mathrm{~mm}$ after the T652 heat treatment of artificial aging. In Fig. 4, the plates after the mechanical processing are shown.

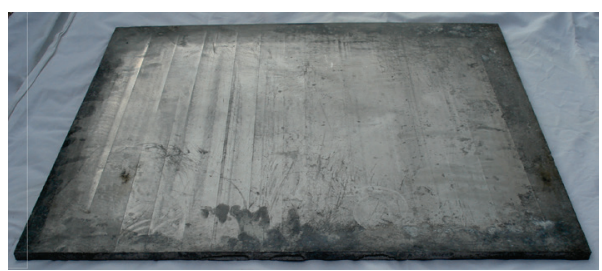

Figure 3 Intermediate product in the form of forging

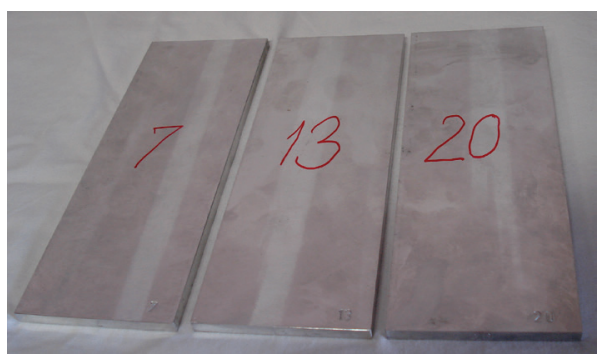

Figure 4 Plates of $180 \times 65 \times 6 \mathrm{~mm}$ after the mechanical processing

Chemical analysis was made on $\mathrm{OE}$ quantimeters ARL 3580 with specimens of "Pechiney" [3].

Chemical composition of experimental plates is provided in Tab. 1 and mechanical properties in Tab. 2 $[3]$.

Table 1 Chemical composition from the batch 1574 of alloy EN AW 7049 A T 652

\begin{tabular}{|c|c|c|c|c|c|c|c|c|c|c|c|}
\hline \multirow{2}{*}{ Alloy type / Batch number } & \multicolumn{11}{|c|}{ Content of elements, wt. $\%$} \\
\hline & $\mathrm{Zn}$ & $\mathrm{Mg}$ & $\mathrm{Cu}$ & $\mathrm{Mn}$ & $\mathrm{Cr}$ & $\mathrm{Zr}$ & $\operatorname{Tr}$ & $\mathrm{V}$ & $\mathrm{B}$ & $\mathrm{Fe}$ & $\mathrm{Si}$ \\
\hline EN AW 7049 A/1574 & 7,28 & 2,25 & 1,58 & 0,29 & 0,18 & 0,14 & 0,15 & 0,007 & 0,003 & 0,16 & 0,09 \\
\hline
\end{tabular}

Table 2 Mechanical properties and hardness of the cast plate from the batch 1574 of EN AW 7049 A T 652 alloy \begin{tabular}{|l|c|c|c|c|}
\hline Alloy type / Batch number & Yield strength, $R_{\mathrm{p} 0,2} / \mathrm{MPa}$ & Ultimate tensile strength, $R_{\mathrm{m}} / \mathrm{MPa}$ & Elongation, $A_{5} / \%$ & $\mathrm{Hardness}, \mathrm{HB}$ \\
\hline
\end{tabular}

\begin{tabular}{l|c|c|c|} 
EN AW $7049 \mathrm{~A} / 1574$ & 506 & 588 & 160 \\
\hline
\end{tabular}

Welding was made in accordance with the plan matrix of experiment, with variations in tool rotation speed $(n)$ and welding speed $(v)$, Tab. 3. Other parameters of welding were maintained constant.

Table 3 Tool rotation speed $(n)$ and welding speed $(v)$

\begin{tabular}{|c|c|c|}
\hline $\begin{array}{c}\text { Experimental } \\
\text { point }\end{array}$ & $\begin{array}{c}\text { Tool rotation speed } \\
n / \mathrm{min}^{-1}\end{array}$ & $\begin{array}{c}\text { Welding speed } \\
v / \mathrm{mm} / \mathrm{min}\end{array}$ \\
\hline ET 05 & 850 & 80 \\
\hline ET 06 & 750 & 60 \\
\hline ET 07 & 750 & 80 \\
\hline ET 08 & 850 & 60 \\
\hline
\end{tabular}

Welding was made on CNC tool milling cutter AG 400, Fig. 5, equipped with welding power and tool oscillation system. The tool was of high alloyed tool steel, heat treated to 54 HRc. The tool is shown in Fig. 6.

Micro hardness was measured in two lines, parallel to the plate surface and perpendicular to that, through the nugget. The distance between the measuring points was $0,5 \mathrm{~mm}$. Micro hardness was measured by using a Shimadzu tester HV2000, with $1 \mathrm{~kg}$ loading. Parameters of the welded joint fracture technique are determined on the Charpy test tubes sampled normally to the direction of welding and with the notch in the centre, at the protruded side and in the withdrawn side of the seam metal. Instrumented Charpy pendulum used was Amsler RPK300. Standard metallographic preparation was conducted, with $5 \% \mathrm{HCl}+2 \% \mathrm{HF}+93 \% \mathrm{C}_{2} \mathrm{H}_{6} \mathrm{O}$ etching agent. The metallographic examination was conducted on Nikon Epiphot-300 light microscope.

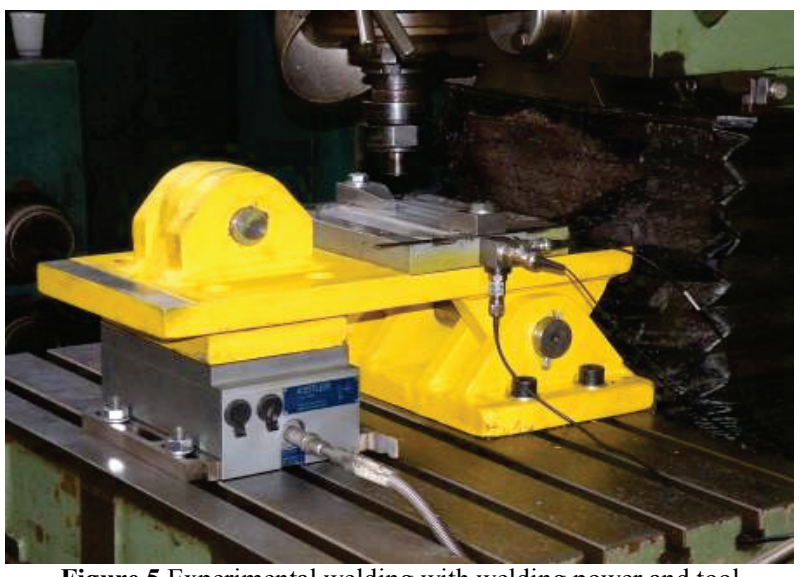

Figure 5 Experimental welding with welding power and tool oscillations measurement system 

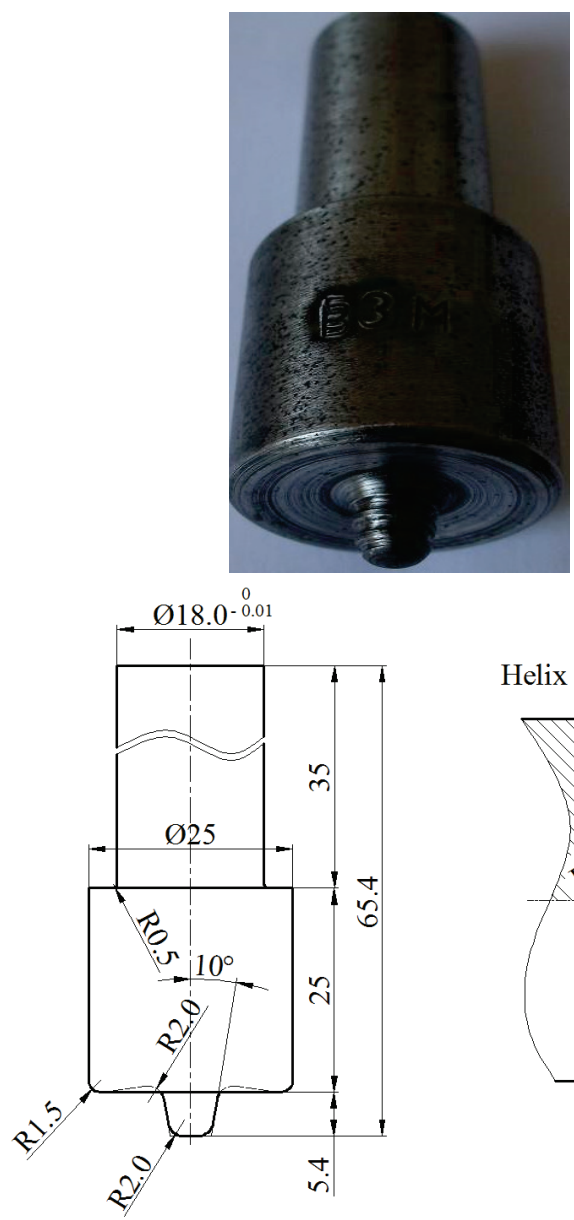

Helix angle $30^{\circ}$

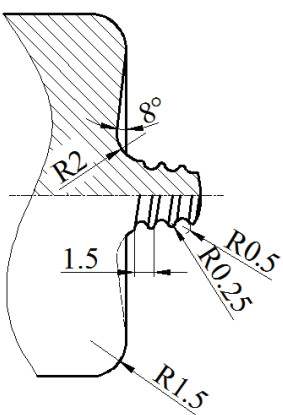

Figure 6 FSW tool

\section{Results}

After the welding process was completed, welds were tested. For that purpose, visual control was performed, on the weld face and root of the seam, as well as the radiographic control of samples. No defects were detected (visually, touch or magnifier). Radiogram of point 5 is shown in Fig. 7, where no defects were found.

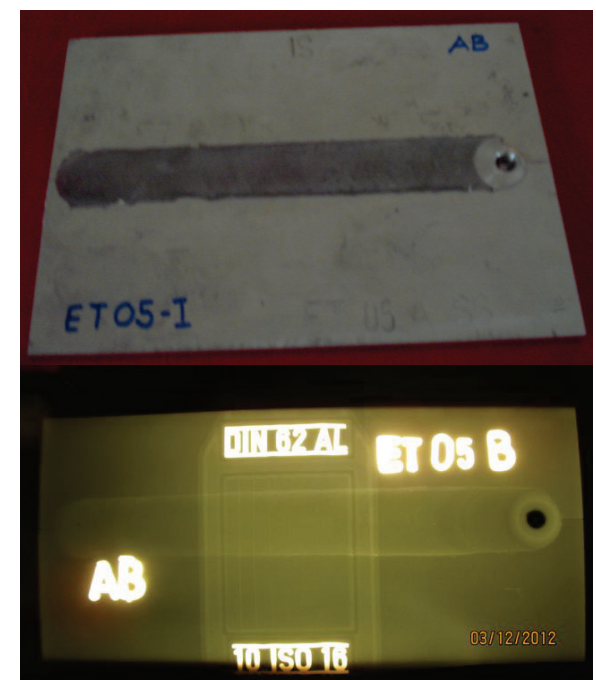

Figure 7 Appearance of the weld face and the interior of the metal in the experimental point 5

Fig. 8 shows the macro graphic of the cross section structure in the 5 point of the experiment.

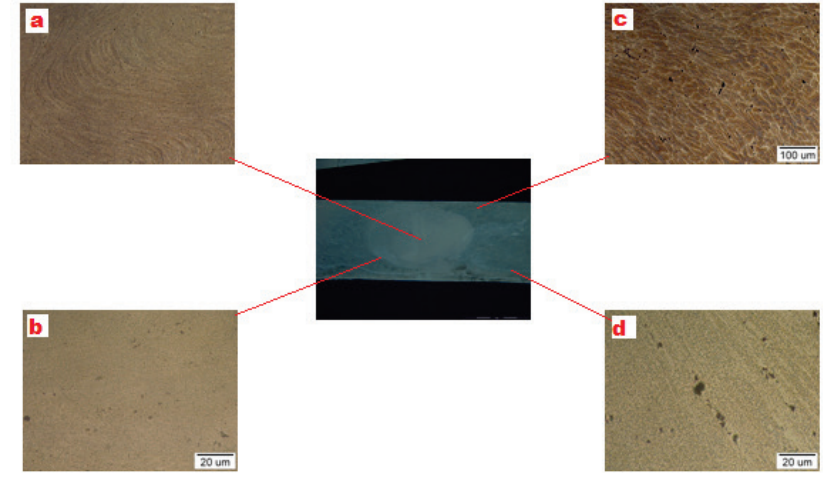

Figure 8 Macro structure of welded joint in point 5 of the experiment with the microstructure of a) nugget zone, b) thermomechanical zone, c) heat affected zone, d) base material

Fig. 9 shows hardness profiles in three levels measurement lines. It can be seen that the high hardness zone in the sub-surface line and the bottom line closely follow the shape of the nugget with its surface widened section obtained by the combined effect of tool pin and tool shoulder. Hardness measurements in line 3 reveal that there are some variations; however, they are not higher than $20 \mathrm{HV}$. Also, it can be seen that there is a marked drop in hardness in the heat affected zone, while the hardness level in the nugget is similar to base metal that is common with heat treated aluminium alloys.

Figs. $10 \div 12$ show the results of impact toughness on instrumented Charpy pendulum. Force and energy dependencies versus time are shown to assess the energy of crack initiation and crack propagation. Fig. 10 shows the results that refer to the results obtained with the specimens taken from the nugget (weld centre), Fig. 11 from the area next to the nugget towards retreating side (4 $\mathrm{mm}$ from weld centre), while in Fig. 12 the results of the specimens taken from the advancing side $(4 \mathrm{~mm}$ from weld centre) are shown. It can be seen that in all specimens, the crack initiation energy is considerably higher than crack propagation energy. In the majority of cases, the increased impact energy also causes an increased energy of crack initiation, as well as crack propagation energy.

\section{Discussion}

On the basis of the metallographic analysis of the weld, it can be seen that there are clear different zones, influenced by the heat generated by tool rotation and translational speed. These both effects also influence the appearance of intensive plastic deformation. Thermomechanical zone was characterized by the refined microstructure and the material flow around the FSW tool pin. Within the basic material, intermetallic phases have been observed. This is result of the heat treatment before FWS welding, when material was prepared.

Micro hardness results shown in Fig. 10 clearly show the nugget zone, with the central part of the chart having the form of the letter "W" in the lower line of the cross section. There are two local micro hardness peaks between the nugget and the thermomechanical zone. Inside the thermomechanical zone, the micro hardness is on the level of, or slightly higher than that of the basic material. A slight decrease in micro hardness can be 
observed in the zone between the thermomechanical and heat affected zones in both line 1 and line 2 . This, relatively small decrease of micro hardness has no significant influence on mechanical properties. In spite of the relatively small values of total impact energy, it can be noticed that the energy of the crack propagation $\left(E_{\mathrm{p}}\right)$ is 2,5 to 3 times the energy of the crack initiation $\left(E_{\mathrm{i}}\right)$ for all examined experimental parameters.
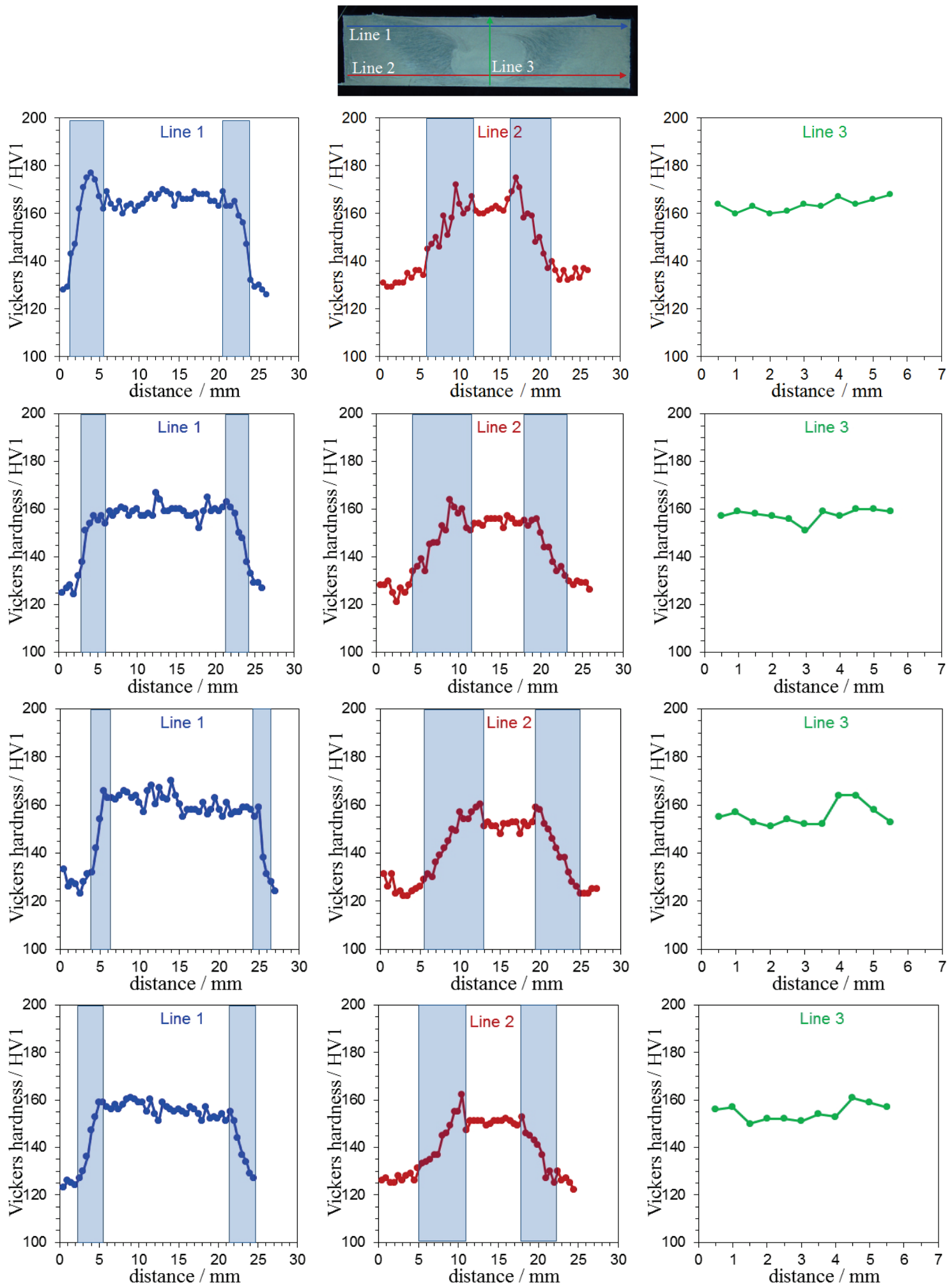

Figure 9 Layout of the micro hardness results measuring in three levels (from top to bottom; experimental points 5, 6, 7 and 8)

The highest values of impact energies in the central, nugget section were measured in specimens obtained with parameters 6 and 7 , both with rotation speed $n$ $=750 \mathrm{~min}^{-1}$ and welding speed of $v=60$ and $80 \mathrm{~mm} / \mathrm{min}$, respectively. In both instances, the ratio between the rotation and welding speed is 10 or slightly over 10 . In the other two sections, with specimens taken from the retreating side, a different relation was obtained. Namely, maximum values of impact energy were obtained in experiments 7 and 8 , with $n=750$ and $850 \mathrm{~min}^{-1}$ and welding speeds of 80 and $60 \mathrm{~mm} / \mathrm{min}$. That means, the ratio between rotation and welding speed is lower than 10 
(for point 7 of the experiment) and higher than 10 (for point 8 of the experiment). Finally, if the notch is located on the advancing side of the weld, the most favourable relation between the rotation and welding speed is higher than 10 , since in experiment point 6 , the welding speed was $750 \mathrm{~min}^{-1}$ and welding speed was $60 \mathrm{~mm} / \mathrm{min}$.
Although it is difficult to assess which experimental point, that is, set of parameters is the most effective, the point $7 \mathrm{a}$ has a slight advantage. With these parameters: $n=750 \mathrm{~min}^{-1}, v=60 \mathrm{~mm} / \mathrm{min}$ and rotation to welding speed of slightly less than 10 , the most balanced impact energies were obtained.
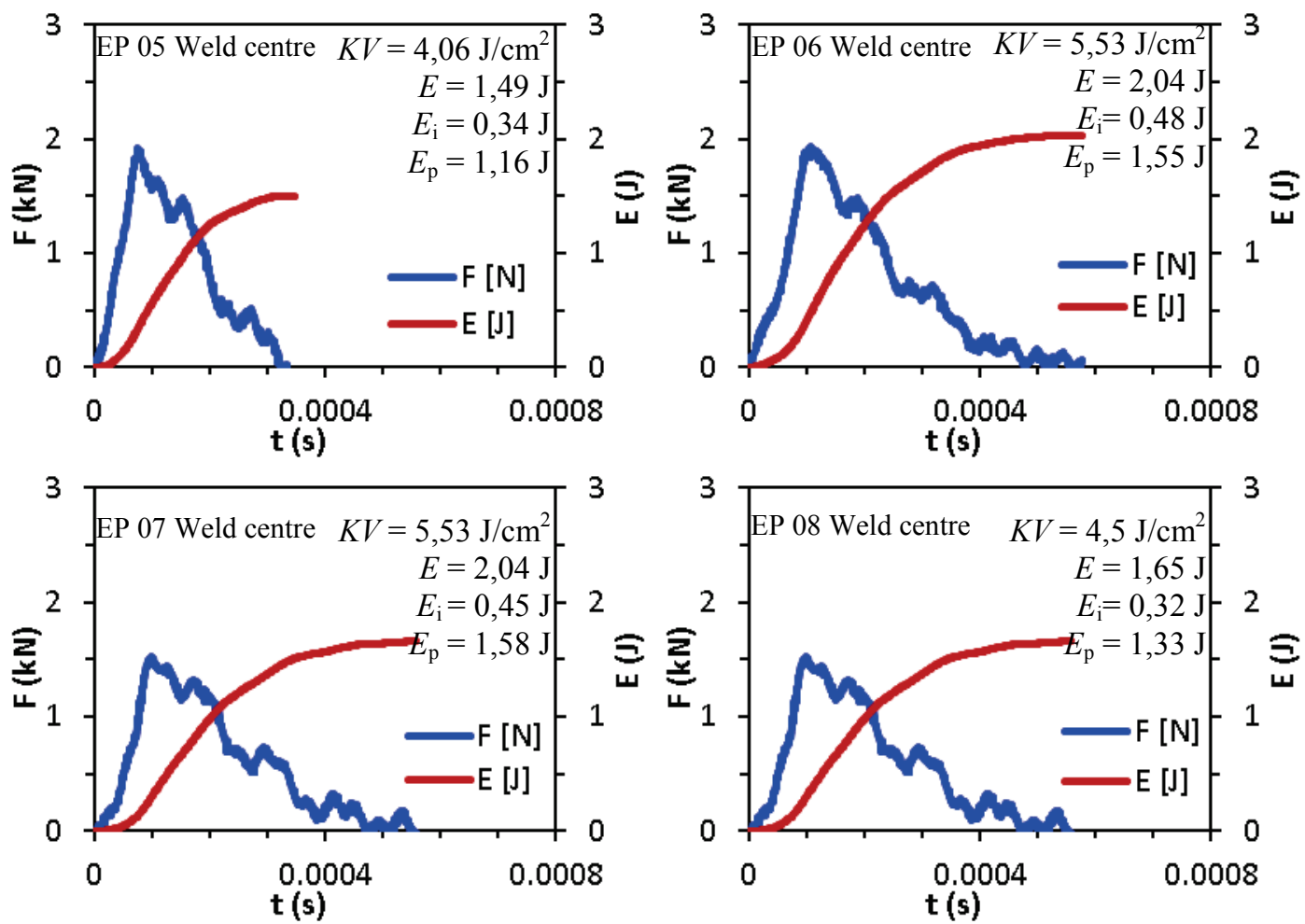

Figure $10 F$ - $t$ and $E$ - $t$ diagrams $\left(K V, E, E_{\mathrm{i}}\right.$ and $\left.E_{\mathrm{p}}\right)$ for experimental points $5,6,7$ and 8 in weld centre
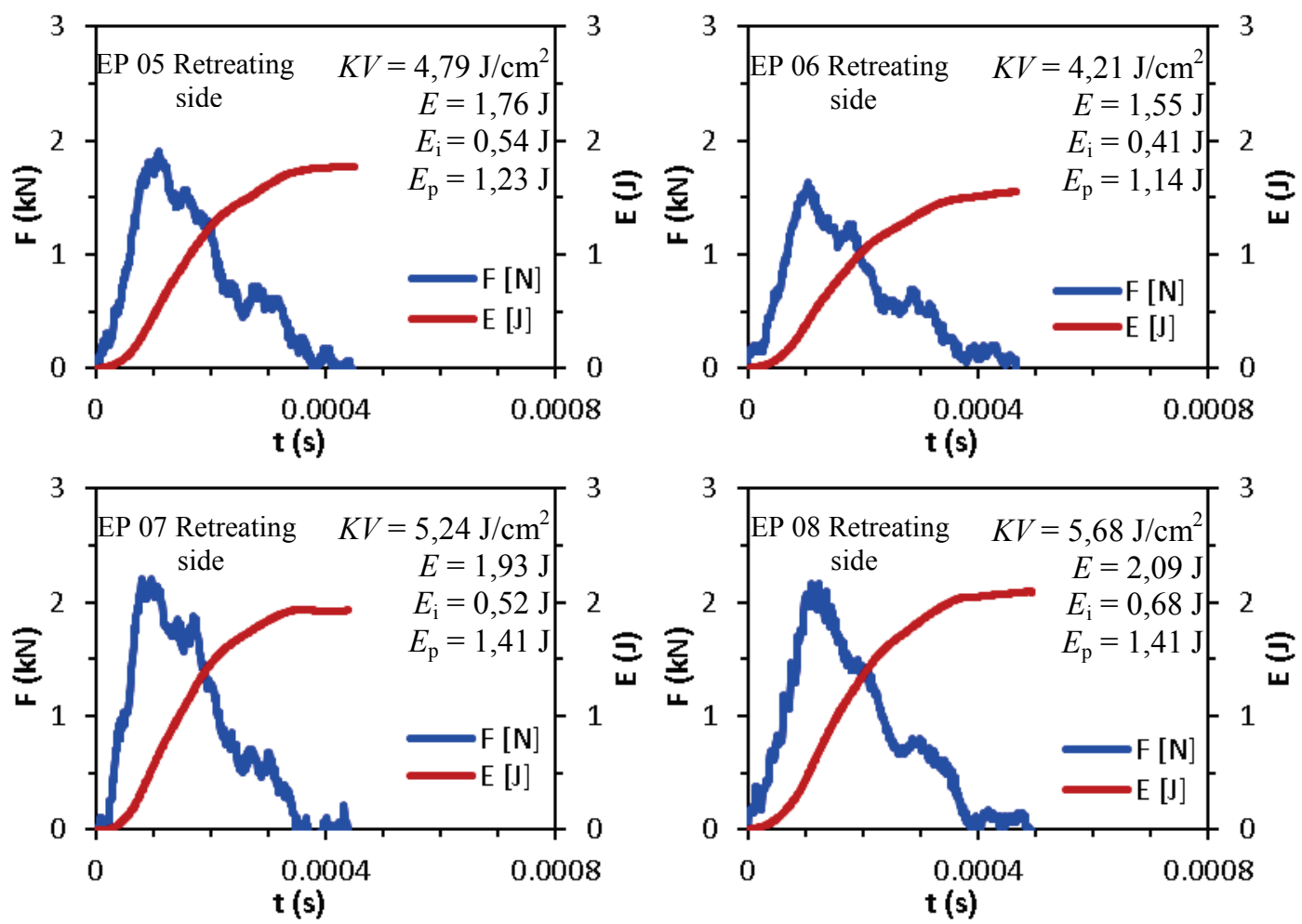

Figure $11 F$ - $t$ and $E$ - $t$ diagrams $\left(K V, E, E_{\mathrm{i}}\right.$ and $\left.E_{\mathrm{p}}\right)$ for experimental points 5, 6, 7 and 8 in retreating side 

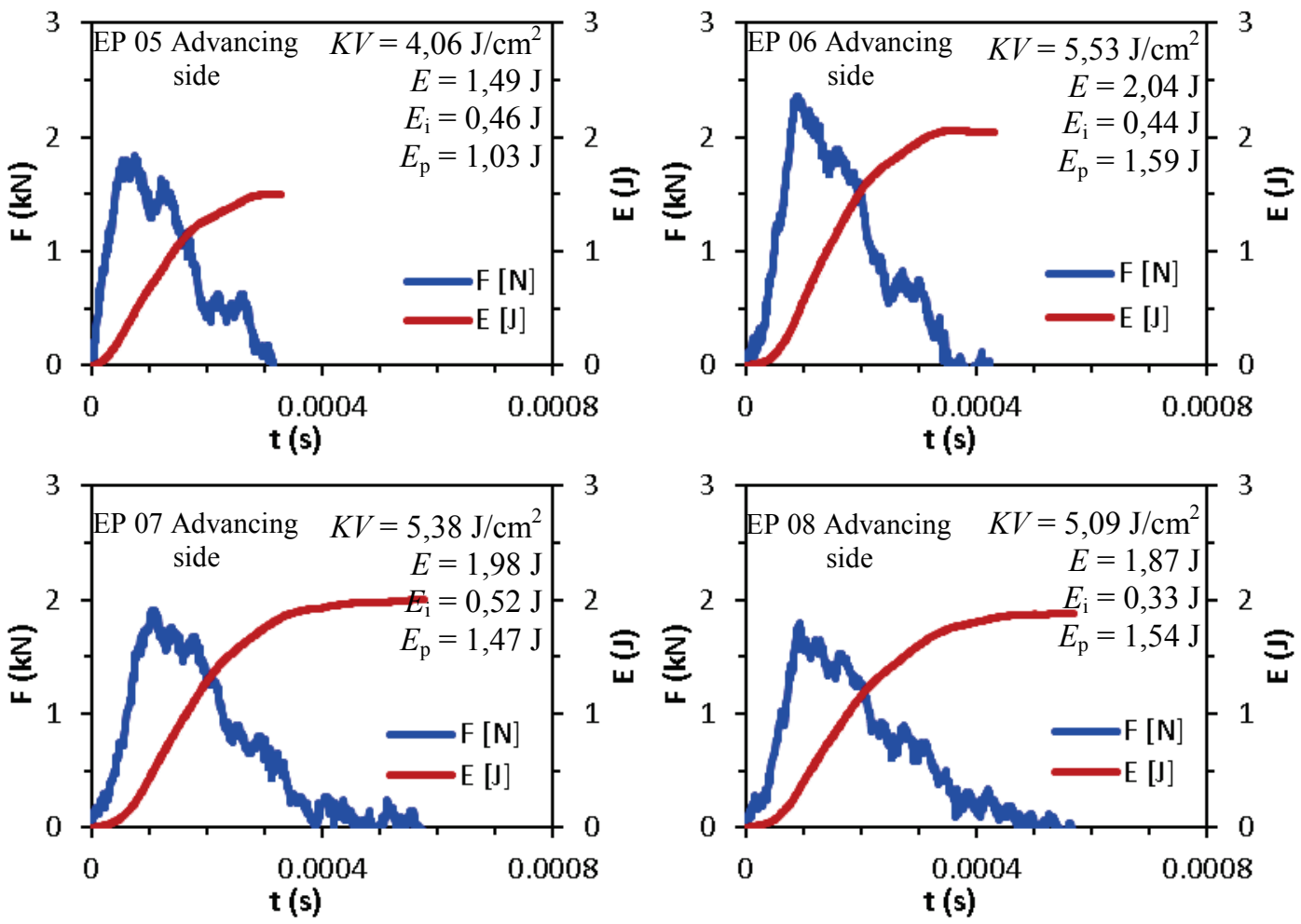

Figure $12 F$ - $t$ and $E$ - $t$ diagrams $\left(K V, E, E_{\mathrm{i}}\right.$ and $\left.E_{\mathrm{p}}\right)$ for experimental points 5, 6, 7 and 8 in advancing side

\section{Conclusion}

On the basis of examinations performed, given results of the experiment and their comparison, the following conclusions can be provided:

- Occurrence of intermetallic phases which are the consequence of the procedure of fabrication and heat treatment of the alloy EN AW 7049 A in condition T652 influence those phases are moved to other areas of the welded joint,

- Profile of distribution and allocation of micro hardness depends on the level of temperature and plastic deformation which is highest under the tool shoulder and around the pin,

- Relation between the number of revolutions of tools $n$ velocity of welding $v$ directly influences the value of the fracture toughness and energy which is required for initiation and propagation of the crack,

- The asymmetry of the welded joint and changes in metallurgical transformations occurring around the pin and under the shoulder of the tool during its combined moving, influence the value of impact strength in various areas of the welded joint.

\section{References}

[1] AWS D17.3/D17.3M: 200x Specification for Friction Stir Welding of Aluminium Alloys for Aerospace Hardware // An American National Standard, American Welding Society/ Miami, Florida, January 2010, p. 60.

[2] Friction Stir Welding - Materials and Thicknesses, http://www.twi.co.uk/j32k/getFile/fswmat.html (09.03.2013)

[3] Projekat proizvodnje legure PD 33, Institut za istraživanje i razvoj aluminijuma SOUR Kombinat aluminijuma, Titograd, 1986.
[4] Mondolfo, L. F. Aluminium Alloys: Structure and Properties. Butterworths, London-Boston, 1976.

[5] ASM Handbook // Properties and Selection, Volume 2, $5^{\text {th }}$ Edition, 1998.

[6] Aluminium Alloys Defence equipment - Cohedur, Peshine Tehnical information.

\section{Authors' addresses}

\section{mr. Milenko Perović}

Chamber of Economy of Montenegro,

Novaka Miloševa 29/II, 81000 Podgorica, Montenegro

E-mail: mperovic@pkcg.org

\section{Dr.sc. Sebastian Baloš, Assistant Professor}

University of Novi Sad,

Faculty of Technical Sciences,

Trg Dositeja Obradovića 6, 21000 Novi Sad, Republic of Serbia

E-mail: sebab@uns.ac.rs

\section{Dr.sc. Dražan Kozak, Full Professor}

Josip Juraj Strossmayer University of Osijek,

Mechanical Engineering Faculty in Slavonski Brod,

Trg I. B. Mažuranić 2, 35000 Slavonski Brod, Republic of Croatia

E-mail: drazan.kozak@sfsb.hr

Dr.sc. Darko Bajić, Associate Professor

(Corresponding author)

University of Montenegro,

Faculty of Mechanical Engineering,

Džordža Vašingtona bb, 81000 Podgorica, Montenegro

E-mail: darko@ac.me

Dr.sc. Tomaž Vuherer, Assistant Professor

University of Maribor,

Faculty of Mechanical Engineering,

Smetanova ulica 17, 2000 Maribor, Slovenia

E-mail: tomaz.vuherer@um.si 